\title{
North America, Central America and the Caribbean (2020)
}

\author{
Kirsten Nakjavani Bookmiller* \\ 12020 : The Year of Compounding Record-Breaking Disasters \\ and New Pressures upon Disaster Law
}

The 2020 COVID-19 pandemic further compounded the suffering of North American, Central American, and Caribbean communities already facing intensifying seasonal natural disaster cycles, among other challenges. The unprecedentedly volatile 2020 Atlantic Ocean hurricane season included 30 named tropical storms, the most yet. It was also the second most active hurricane season ever recorded, ${ }^{1}$ including November Hurricanes Eta and Iota, successively striking Central America and Colombia just two weeks apart. With their attendant flooding and landslides, the tandem events impacted millions in the region, including nearly half of Honduras' entire population; the combined devastation equal only to that of 1998 Hurricane Mitch. ${ }^{2}$ The United States (US) also suffered its most catastrophic wildfire season in history, partly fueled by a larger "megadrought" pattern in its southwest. ${ }^{3}$ These combined climate-related disasters caused the Americas to incur $53 \%$ of total global economic losses in 2020 , with the US the most economically impacted not only within the region but also worldwide. ${ }^{4}$

* PhD in Foreign Affairs (University of Virginia); Professor, Department of Government, Policy, and Law and Center for Disaster Research and Education, Millersville University (USA); Disaster Law Focal Point for North America, Central America, and the Caribbean, IFRC Disaster Law Program for the Americas.

1 World Meteorological Organization, 'Record-breaking Atlantic Hurricane Season Ends' (1 December 2020) <https://public.wmo.int/en/media/news/record-breaking-atlantic-hurri cane-season-ends $>$, last accessed (as any subsequent URL) on 18 June 2021.

2 UNDRR, UC Louvain, CRED and USAID, '2020: The Non-Covid Year in Disasters' (2021) $<$ https://reliefweb.int/sites/reliefweb.int/files/resources/2020\%2O-\%2othe\%2onon -COVID\%2oYear\%2oin\%2oDisasters\%2o-\%2oGlobal\%2oTrends\%2oand\%2oPerspectives .pdf $>$, at 3 .

3 Alejandra Borunda, 'Megadrought Persists in Western U.S., as Another Extremely Dry Year Develops' National Geographic (7 May 2021) < https://www.nationalgeographic.com/ environment/article/megadrought-persists-in-western-us-as-another-extremely-dry-year -develops>.

4 See UNDRR, UC Louvain (n 2$) 1$. 
Despite these record-breaking disasters, CoviD-19 became the top cause of death in most Latin American and Caribbean countries in 2020. On 11 March, the WHO categorized COVID-19 as a pandemic; by 19 March, its existence was reported in every Latin American country. 'In some countries, the virus and its reverberations have canceled out the reduction in deaths from disasters achieved during the implementation period of the Hyogo Framework between 2005 and 2015' according to the UN Office for Disaster Risk Reduction (UNDRR). ${ }^{5}$ By year's end, the US had the highest global COVID-19 related death toll, with an estimated 35 , ooo lives lost. ${ }^{6}$

The pandemic complicated responses to the more commonplace socionatural disasters striking the region, overloading already strained national emergency management systems and challenging standard protocols, including evacuation plans. ${ }^{7}$ CoviD-19 also further exposed the many cross-cutting vulnerabilities throughout the area, including underresourced health systems and social protection mechanisms, urban overcrowding, and political and socio-economic fragility. For the first time on record, the crisis contracted all of the region's national economies simultaneously, with the OECD finding that the socio-economic blow to Latin America and the Caribbean was the worst of any region globally. ${ }^{8}$ Such impacts jeopardized earlier progress toward achieving both the 2030 Agenda for Sustainable Development goals and the Sendai Framework for Disaster Risk Reduction (Sendai) targets. ${ }^{9}$ Subsequent

5 UNDRR, 'Regional Assessment Report on Disaster Risk in Latin America and the Caribbean' (2021) < https://www.undrr.org/media/48868/download > 7 .

6 Farida Ahmad and Robert Anderson, 'The Leading Cause of Death in the US for 2020' JAMA (31 March 2020) <https://jamanetwork.com/journals/jama/fullarticle/2778234>.

7 See for example Edward Struzik, 'Canada: How Coronavirus Could Make a Bad Wildfire Season Even Worse' The Conversation (22 April 2020) <https://theconversation.com/how -coronavirus-could-make-a-bad-wildfire-season-even-worse-134956>, Matthew Lavietes, 'Coronavirus Pandemic Threatens to Suffocate U.S. Hurricane Response' Thomson Reuters Foundation News (13 May 2020) <https://news.trust.org/item/20200513082815-8hzfr/> and Anastasia Moloney, 'At-risk Caribbean Scrambles to Prepare for Hurricanes During Pandemic' Reuters (3 August 2020) <https://www.reuters.com/article/us-health-corono virusa-caribbean-storms/at-risk-caribbean-scrambles-to-prepare-for-hurricanes-during -pandemic-idUSKCN250o1Z>.

8 OECD, 'COVID-19 in Latin America and the Caribbean: Regional Socio-economic Implications and Policy Priorities' (8 December 2020) <https://www.oecd.org/coronavirus/ policy-responses/covid-19-in-latin-america-and-the-caribbean-regional-socio-economic -implications-and-policy-priorities-93a64fde/>.

9 See UndrR, 'Regional' (n 5) 9. 
government measures also raised serious questions regarding human rights infringements in many instances. ${ }^{10}$

The Americas has considerable experience with cooperatively managing public health emergencies, including Dengue, Cholera, and Zika. The pandemic response, however, consisted of a patchwork of approaches, often to deadly effect. Many national governments opted to unilaterally address the crisis - including the region's biggest, Brazil, Mexico, and the United States while sidelining regional and international mechanisms and legal frameworks in the process. The United States went so far as to formally notify wHO of its intent to withdrawal in July 2020. ${ }^{11}$ Pandemic denialism, misinformation, hyperpolitization, and besieged health systems further stymied effective action. $^{12}$

Still, other countries in the area did their best to adhere to World Health Organization recommendations - mainly the International Health Regulations (IHR) and the Strategic Preparedness and Response Plan and leverage regional networks, including through the Pan American Health Organization (РAHO). ${ }^{13}$ Specific subregional collaboration around the pandemic, including through the Central American Integration System (SICA), the Caribbean Community (CARICOM), and the Caribbean Public Health Agency (CARPHA), will be further highlighted below.

The COVID-19 pandemic has prompted a still unfolding regional and global conversation as to how best to fulfill Sendai's objectives in light of simultaneous multi-hazard threats, along with many other disaster law questions. ${ }^{14}$

10 See for example Solidar, 'Impact of Covid-19 on Central America' (2020) <https://relief web.int/sites/reliefweb.int/files/resources/Solidar-COVID-en202o-V6.pdf > and Peter Hotez, Jorge Huete-Perez and Maria Bottazzi, 'Covid-19 in the Americas and Erosion of Human Rights for the Poor' PLoS Neglected Tropical Diseases $(2020)<$ https://journals .plos.org/plosntds/article?id=10.1371/journal.pntd.ooo8954>.

11 The Trump administration's decision would not have legally taken full effect until July 2021; the incoming Biden administration rescinded the decision in January 2021.

12 See for example Luke Taylor, 'How Latin America is Fighting Covid-19, For Better and Worse' вмJ (1 September 2020) <https://www.bmj.com/content/370/bmj.m3319> and Paulo Estevez, 'Latin America's Uncoordinated Response in Tackling Covid-19' South African Institute of International Affairs (2020) <https://www.jstor.org/stable/pdf/res rep29594.pdf?refreqid=excelsior\%3Af7b9999o922d39c84a71cbo40o2faege >.

13 PAHO, 'Pan American Health Organization Response to Covid-19 in the Americas' (2020) <https://reliefweb.int/sites/reliefweb.int/files/resources/paho-response-covid-19 -americas-31-may-2020-v6.pdf>.

14 ECLAC-UndrR, 'The Coronavirus Disease (Covid-19) Pandemic: An Opportunity For a Systemic Approach to Disaster Risk For The Caribbean' (March 2021) <https://www .cepal.org/sites/default/files/publication/files/46732/S20oo944_en.pdf) $>21$ and Riyanti Djalante, Rajob Shaw and Andrew DeWit, 'Building Resilience Against Biological Hazards 
In the meantime, this report will highlight international disaster law-related progress within the North American, Central American, and Caribbean subregions outside of COVID-19 responses, as well as early legal developments spurred by 2020's extraordinary public health emergency.

2

\section{0: The Year of Sendai's Target $\mathrm{E}$ and Other Region-Wide} Developments

Sendai's Global Target E urges the world community to 'Substantially increase the number of countries with national and local disaster risk reduction strategies by 2020'. According to the UNDRR 2020 Annual Report, $69 \%$ of countries in the Americas and Caribbean had national DRR strategies aligned with Sendai in place or in process by $2020 .{ }^{15}$ Another UNDRR assessment specifically focused upon Latin America and the Caribbean commended progress to date in CARICOM and SICA countries, but expressed concern regarding the significant lack of local-level plans. ${ }^{16}$

The pandemic forced a meeting postponement of the VII Regional Platform for Disaster Risk Reduction in the Americas and the Caribbean (RP21), initially scheduled for July 2020. As of this writing, it is rescheduled for November 2021 and will be convened remotely. In the meantime, knowledge exchanges continued. For example, UNDRR offered training workshops for 16 countries on disaggregated disaster data reporting using the DesInventar system. This data is incorporated into the Sendai Framework Monitoring (SFM) process addressing Global Targets A (disaster mortality) and B (number of people affected). ${ }^{17}$

\section{3} North America

The pandemic struck Mexico and the United States especially hard. By late March, both they and the United States and Canada mutually agreed to close

and Pandemics: covid-19 and Its Implications for the Sendai Framework' (April 2020) <https://www.sciencedirect.com/science/article/pii/S259006172030017X $>$.

15 UNDRR, 'Annual Report 2020' (2021) <https://www.undrr.org/publication/undrr-annual -report-2020>37.

16 See UNDRR, 'Regional' ( $\mathrm{n}_{5}$ ) 12.

17 The countries are Antigua and Barbuda, Barbados, Belize, Costa Rica, Dominica, Dominican Republic, Grenada, Jamaica, Mexico, Panama, Paraguay, Peru, Saint Kitts and Nevis, Saint Lucia, Saint Vincent and the Grenadines, Trinidad and Tobago. UNDRR, 'Annual' (n 15) 24. 
their respective land borders to all non-essential travel while allowing commercial traffic to continue. ${ }^{18}$ This exemption emerged after the September 2001 terrorist attacks, when a complete shutdown between Canada and the US involving the longest shared land border in the world - caused significant economic chaos. ${ }^{19}$ These bilateral arrangements continued into 2021.

The Mexican and United States governments were both heavily criticized for their similarly intentional hands-off national approaches, resulting in high death tolls in each instance. ${ }^{20}$ Yet the somewhat unique federal governing systems within all three countries, ${ }^{21}$ in which emergency management and public safety matters legally devolve to subnational authorities, added further complications. With Canada's asymmetrical federalism, each province determines the nature of its relationship with the national government. Only the federal level's invocation of the 1985 Emergencies Act can supplant this arrangement, when necessitated by an event that outstrips the provinces' ability to respond. Controversially, especially as COVID-19 case rates began to climb, the Trudeau government never utilized the 1985 law, resulting in a piecemeal province by province response. $^{22}$

In Mexico, the federal government belatedly summoned the constitutionally derived General Health Council, which in turn invoked its singular authority to declare a national health emergency in late March. Despite the law's intent to better standardize the response across the states, it remained decentralized in reality, further aggravated by tension between President Obrador's government

18 US Department of Homeland Security, 'Fact Sheet: DHS Measures on the Border to Limit the Further Spread of Coronavirus' (23 March 2020) <https://www.dhs.gov/ news/2020/10/19/fact-sheet-dhs-measures-border-limit-further-spread-coronavirus $>$.

19 Alexander Panetta, 'How the Shutdown After 9/11 Paved the Way For the New CanadaU.S. Border Response To COVID-19' свс News (20 March 2020) <https://www.cbc.ca/ news/world/coronavirus-covid-19-border-canada-united-states-trade-1.55०3192>.

Mary Beth Sheridan, 'Mexico's Pandemic Policy: No police. No curfews. No fines. No regrets.' Washington Post (26 January 2021) <https://www.washingtonpost.com/world/ the_americas/coronavirus-mexico-lockdown-lopez-obrador/2021/01/25/8d6311aa-5ofc -11eb-aif5-fdaf28cfca9o_story.html>; Mary Van Beusekom, 'US Leads 19 Nations in Covid-19, All-Cause Death Rates' CIDRAP [University of Minnesota] (12 October 2020) <https:// www.cidrap.umn.edu/news-perspective/2020/10/us-leads-19-nations-covid-19-all -cause-death-rates $>$.

21 No other countries covered by this entry possess federal systems. The only others within the Americas are Brazil and Venezuela.

22 Amy Swiffen, 'The Limits of Canada's Federal Emergency Law During the Coronavirus Pandemic' The Conversation (1 April 2020) <https://theconversation.com/the-limits -of-canadas-federal-emergency-law-during-the-coronavirus-pandemic-134309>; FASKEN, 'Canadian Health Sector: Covid-19 Update' (27 July 2020) <https://www.fasken.com/en/ knowledge/2020/o7/27-covidig-canadian-health-sector-update>. 
and states led by opposition parties. ${ }^{23}$ The legally fragmented response within the United States also became a salient feature of that country's ineffectual pandemic management, among many other challenges. As one legal expert notes, 'America's defense against epidemics is divided among 2,684 state, local, and tribal public health departments.' ${ }^{24}$

Separate from COVID, the UNDRR recognized that all three countries had national DRR strategies aligned with Sendai in place or in process by the end of 2020, per Global Target E. ${ }^{25}$ In furtherance of the framework's implementation, Public Safety Canada and the Canadian Risk and Hazards Network virtually held their annual National Roundtable for DRR in October and November, dedicated to enhancing resilience-focused governance and a cross-sector understanding of disaster risk. ${ }^{26}$ Due to the pandemic, British Columbia adjusted its timeline to introduce new Emergency Management legislation aligned with Sendai (the first province in Canada to do so) from 2021 to 2022. Still, the provincial authority did release a stakeholder feedback document on the proposed legislation, titled 'What We Heard'. It incorporated input from 239 submissions across government, business, and civil society. British Columbia reopened the process to consider developments related to the Covid-19 crisis. $^{27}$

UNDRR also promoted ARISE Mexico's new Resilience Tool addressing business continuity during the COVID-19 pandemic as a best practices instrument. The tool was developed in partnership with CitiBanamex and the UN's Global Compact initiative and aligns with Sendai, the Agenda for Sustainable Development and the Paris Climate Pact. ${ }^{28}$ The Mexican Space Agency

23 Pablo Hiriart, 'Gobernadores rechazan migajas' El Financiero (16 April 2020) <https:// www.elfinanciero.com.mx/opinion/pablo-hiriart/gobernadores-rechazan-migajas/>; Mauricio Guim, 'Mexico's Untimely Fight Against Coronavirus' (27 May 2020), <https:// www.theregreview.org/2020/o5/27/guim-mexico-untimely-fight-against-coronavirus/>. Polly Price, 'A Coronavirus Quarantine in America Could Be a Giant Legal Mess' The Atlantic (16 February 2020) <https://www.theatlantic.com/ideas/archive/2020/o2/corona virus-quarantine-america-could-be-giant-legal-mess/606595/>. See also Jamison Chung, 'How Federalism Has Harmed Public Health' The Regulatory Review (23 December 2020) <https://www.theregreview.org/2020/12/23/chung-federalism-harmed-public-health/>.

25 See UNDRR, 'Annual' (n 15) 37.

26 CRHNet, '2020 Virtual CRHNet Symposium and DRR Roundtable' <https://crhnet.ca/ events-list/202o-virtual-crhnet-symposium-roundtable/>.

27 British Columbia, 'Modernized Emergency Management Legislation' (10 May 2021) <https://www2.gov.bc.ca/gov/content/safety/emergency-preparedness-response-reco very/emergency-management-bc/legislation-and-regulations/modernizing-epa $>$.

28 'ARISE MX Launches Resilience Protocol For MSMES in the Face of the Pandemic' (15June 2020) <https://arise.mx/en/lanza-arise-mx-protocolo-de-resiliencia-para-mi pymes-ante-la-pandemia/>. 
formed, with the National Commission for Space Activities of Argentina, the Comprehensive Regional Satellite Information System (SIRIS). This shared digital platform seeks to integrate the countries' satellite data to support environmental monitoring and disaster management across the Americas, primarily related to agriculture, forestry, and disease control. ${ }^{29}$

\section{$4 \quad$ Central America}

Central America has consistently ranked as one of the most disaster risk-prone subregions globally, with high levels of exposure to both hydrometeorological and geophysical hazards. ${ }^{30}$ The pandemic added yet another acute level of societal stress for many countries that were already struggling with abundant endemic challenges, including extreme socio-economic disparities, political fragility, food insecurity, and outward migration in the "Northern Triangle" countries of El Salvador, Guatemala, and Honduras. National responses varied across the region from stringent quarantine measures in places such as El Salvador and Panama to the Nicaraguan government's complete dismissal of the pandemic's threat. ${ }^{31}$

Despite these substantial problems, the subregion's intergovernmental body SICA, and its Coordination Center for the Prevention of Disasters in Central America and the Dominican Republic (CEPREDENAC), proactively initiated a series of joint measures, just one day after the wHo declared the pandemic. On 12 March, the sICA Heads of States and Governments convened an extraordinary meeting, issuing the Central America Allied Against the Coronavirus Declaration. The statement called for the creation of a Regional Contingency Plan for pandemic response. CEPREDENAC took up the charge, drafting a Regional Contingency Plan to augment national response efforts, establishing a regional situation room and a SICA-COVID-19 Information and

29 UN Office for Outer Space Affairs, 'Mexico and Argentina Align Satellite Networks to Resolve Regional Challenges' (20 December 2020) <https://www.un-spider.org/news-and -events/news/mexico-and-argentina-align-satellite-networks-resolve-regionalchallenges $>$.

30 UNOCHA, 'Natural Disasters in Latin America and the Caribbean, 2000-2019' (March 2020) $<$ https://reliefweb.int/sites/reliefweb.int/files/resources/20191203-ocha-desastres_natu rales.pdf $>$.

31 Christopher Sabatini, 'Latin America's Covid-19 Moment: Difference and Solidarity' Chatham House (30 April 2020) <https:/www.chathamhouse.org/2020/04/latin-ame ricas-covid-19-moment-differences-and-solidarity>; Carrie Kahn, 'Citizens Work to Expose COVID's Real Toll in Nicaragua as Leaders Claim Success' NPR (12 May 2021) $<$ https://www.npr.org/2021/05/12/996122094/citizens-work-to-expose-covids-real-toll-in -nicaragua-as-leaders-claim-success $>$. 
Coordination Platform, and facilitating national peer information exchanges. In all of these endeavors, CEPREDENAC notes that Sendai informs its work. ${ }^{32}$

While the devastation wrought by Hurricanes Eta and Iota was an unwanted reminder of the subregions' ongoing multi-hazard threats outside of the COVID-19 pandemic, disaster law played a significant role during the crises. Ahead of both events, sICA activated the 2014 Regional Mechanism for Mutual Humanitarian Assistance to Disasters of the Central American Integration System (MecReg-SICA), expediting cooperation in response, recovery, technical assistance, and situation reports. ${ }^{33}$ Eta even spurred the National Congress of Honduras to formally approve the Act on the Facilitation of International Humanitarian Disaster Assistance and Initial Recovery (Decree 147-2020) on 13 November, after making its way through the legislative process throughout 2020. The new law was fully based on the International Federation of Red Cross and Red Crescent Societies (IFRC) International Disaster Response Law (IDRL) Model Law - the first ever to be so in the Americas - and helped shape the international assistance process for both Eta and Iota. ${ }^{34}$ Subsequently, the Honduran Red Cross, the IFRC, and various government ministries drafted a new IDRL Regulation to implement the new act. Following Eta's devastation upon Guatemala, that government structured its official request for international assistance utilizing the IF RC Model Emergency Decree. ${ }^{35}$

Regarding DRR-related law, in September 2020, CEPREDENAC concluded a Memorandum of Understanding with the Secretariat for Central American Tourism Integration to promote risk reduction and bolster resilience among members' tourism sectors. ${ }^{36}$ UNDRR also recognized four countries in the region, Costa Rica, Guatemala, Honduras, and Panama, as having made

32 UNDRR, 'Central America Allied Against the Coronavirus COVID-19' $(2020)<$ https://www .undrr.org/publication/central-america-allied-against-coronavirus-covid-19>; UNDRR, 'New Online Platform to Help Shape Regional Pandemic Response' (29 April 2020) <https:// www.undrr.org/news/new-online-platform-help-shape-regional-pandemic-response>.

33 Bnamericas, 'SICA Coordinates Actions Against Climatological Impacts in Central America' (17 November 2020) <https://www.bnamericas.com/en/news/sica-coordinates -actions-against-climatological-impacts-in-central-america>; CEPREDENAC and SICA, 'Informe de Situación Huracán IOTA' (19 November 2020) <http://cepredenac.org/wp -content/uploads/2020/11/informe-de-situacio\%CC\%81n-IOTA-7.pdf >. The first version of MecREd-sicA was issued in 2001 and has been continually updated.

34 IFRC Disaster Law Annual Report 2020, 8-9. For the original text of this new law, refer to $<$ https://www.aduanas.gob.hn/wp-content/uploads/2020/11/Gaceta-20201114.pdf >.

35 Ibid., 8.

36 Sitca, 'CEPREDENAC y SITCA Firman Memorando de Entendimiento Para Mejorar La Gestión del Riesgo de Desastres en El Sector Turístico Regional' (17 September 2020) $<$ https://sitca.info/2020/o9/cepredenac-y-sitca-firman-memorando-de-entendimiento -para-mejorar-la-gestion-del-riesgo-de-desastres-en-el-sector-turistico-regional >. 
progress toward Sendai's Global Target E, with national DRR strategies either in place or underway by $2020 .{ }^{37}$

\section{$5 \quad$ The Caribbean}

In contrast to the 2020 experience of North America and Central America, the Caribbean's Covid-19 cases remained relatively low in both absolute and per capita terms (although the Dominican Republic and Haiti were notable exceptions). Observers attributed the subregion's deep well of experience responding to hurricanes and epidemics as contributing factors. Citizens were already accustomed to stay-at-home orders, curfews, and other government mandates. Authorities also capitalized upon vibrant regional disaster management mechanisms long in place, including CARICOM and its auxiliary arms, the Caribbean Disaster Management Agency (CDEMA) and the Caribbean Public Health Agency (CARPHA). Member states jointly issued pandemic control measures ahead of the first cases arriving in the region in March. ${ }^{38}$

Yet the real catastrophe for the area was economic; with $14 \%$ of combined GDP dedicated to tourism - the highest in the world - initial border closures and the global tourism industry's collapse shattered the region's economies. Acute job loss, food insecurity, and rising poverty levels became a profound concern. As Barbados' Prime Minister Mia Mottley characterized the devastation: "This [COVID-19] has exposed our people and our economies in a way that we have not experienced since becoming independent nations more than fifty years ago in some instances.' 39

As CARICOM's Chair, Prime Minister Motley convened a Special Emergency Meeting of the Heads of Government to formulate a regional pandemic response plan on 1 March. The group expressed its early support for CARPHA's Draft Health Sector Response Guidelines for COVID-19, detailing response

37 See UNDRR, 'Annual' (n 15) 37.

38 Ian Hambleton, Selvi Jeyaseelan, Madhuvanti Murphy, 'Covid-19 in the Caribbean Small Island Developing States: Lessons Learnt from Extreme Weather Events' The Lancet (2 July 2020) <https://www.thelancet.com/journals/langlo/article/PIIS2214-109X (20)30291-6/fulltext>.

39 PAHO, 'Prime Minister of Barbados and Chair of the Conference of Heads of Government of CARICOM address the 73rd World Health Assembly' (18 May 2020) <https://www .paho.org/en/news/18-5-202o-prime-minister-barbados-and-chair-conference-heads -government-caricom-address-73rd>. 
protocols and guidelines for better coordination with the cruise ship industry. ${ }^{40}$ It also issued numerous other instruments, including a coviD-19 Checklist for National Disaster Coordinators, a Logistics Supply Chain Guidance note, and a Continuity of Planning Guidance Note. ${ }^{41}$

While CARPHA's Regional Coordinating Mechanism for Health Security (RCM-HS) served as technical lead, CARICOM also triggered CDEMA's longstanding Regional Response Mechanism (RRM), a multi-tiered humanitarian response surge arrangement facilitating cooperation between national, regional, and international aid providers. The mechanism operationalizes CDEMA's Regional Disaster Response Support Doctrine. ${ }^{42}$ In subsequent months, CARICOM issued further health, border, and airline travel protocols and a COVID-19 Agri-Food Security Action Plan, among several other pandemicrelated soft law instruments. ${ }^{43}$ Many of CARPHA's specific contributions in these areas were informed by the IH R. ${ }^{44}$ Individual countries also referenced the IHR related to rendering medical assistance to cruise ship passengers and crew in the earlier stages of the pandemic. ${ }^{45}$

As elsewhere, Caribbean states were reminded of an even more intense multi-hazard landscape than usual, encountering a record-breaking tropical storm season and the eruption of La Soufrière volcano in St. Vincent and the Grenadines in December. Despite the demands of the pandemic response, CDEMA and other regional stakeholders continued to advance disaster law

40 'CARICOM Heads Agree on Coronavirus Protocol' (3 March 2020) Stabroek News $<$ https://www.stabroeknews.com/2020/o3/o3/news/guyana/caricom-heads-agree -on-coronavirus-protocol/>. CDEMA, 'COVID-19 Outbreak in CDEMA Participating States' (16 March 2020) <https:// www.cdema.org/CDEMA_Situation_Report_1_-_COVID_19_Outbreak.pdf>.

42 Regional Response Mechanism, 'What is the Covid-19 Integrated Regional Logistics Hub?' $<$ https://www.cdema.org/rrm/index.php/covid-19>.

43 The Caribbean Council, 'CARICOM Heads Agree to Develop Common Responses to Challenges Posed by COVID-19' <https://www.caribbean-council.org/caricom-heads -agree-to-develop-common-responses-to-challenges-posed-by-covid-19/>; The Caribbean Council, 'CARICOM Heads Agree to Steps Required to Reopen the Regional Economy' $<$ https://www.caribbean-council.org/caricom-heads-agree-to-steps-required-to-re open-the-regional-economy/>.

44 CARPHA, 'Regional Guidelines for Response' <https://carpha.org/THP/Regional-Guide lines-for-Response>.

45 'COVID-19: Barbados Has Six Confirmed Cases on Island' Loop News (20 March 2020) $<$ https://barbados.loopnews.com/content/covid-19-barbados-has-six-confirmed-cases -island>; 'St. Kitts and Nevis Takes Preventative Action Against Coronavirus' Travel Agent Central (5 March 2020) <https://www.travelagentcentral.com/caribbean/st-kitts-nevis -takes-preventative-action-against-coronavirus $>$. 
development and implementation in several areas, especially pertaining to DRR. A major achievement relates to one of the agency's signature initiatives, the Multi-Hazard Early Warning System (MHEws). At its July meeting, the CDEMA Council formally endorsed the Model National Multi-Hazard Early Warning System Policy and Adaptation Guide, following major preparatory work among participating states throughout 2019. ${ }^{46}$ The agency also signed a Regional Early Warning Systems Consortium Memorandum of Understanding with the Caribbean Agricultural Research \& Development Institute in February. ${ }^{47}$ Impressively, the agency also launched in November the Caribbean Risk Information System (CRIS) platform, a centralized knowledge exchange resource designed to further disaster resilience and sustainable development in the region. ${ }^{48}$

Several governments also progressed important domestic level initiatives. By late 2020, UNDRR reported that eight countries in the region had national DRR strategies adopted or underway to implement Sendai's Global Target E, including Antigua and Barbuda, Barbados, Cuba, Grenada, Haiti, Saint Lucia, Saint Vincent and the Grenadines, and Trinidad and Tobago. ${ }^{49}$ Haiti passed its National Risk and Disaster Management Plan 2019-2030 after a highly consultative process, explicitly noting the role Global Target E played in animating the process and the plan's intentional positioning within several global, regional and domestic frameworks. ${ }^{50}$ Dominica released its Climate Resilience and Recovery Plan, operationalizing its 2018 Climate Resilience Act that was passed after the destruction wrought by Hurricane Maria in 2017.51 Lastly, in partnership with the Trinidad and Tobago Red Cross Society and the IFRC, Trinidad and Tobago launched a review process of its disaster risk management

46 CDEMA, 'The CDEMA Council Recognizes the Role of the Agency in the Fight Against COVID-19' (6 July 2020) <https://www.cdema.org/news-centre/press-releases/2056-the -cdema-council-recognises-the-role-of-the-agency-in-the-fight-against-covid-19>.

CDEMA, 'CDEMA and CARDI Sign Regional Early Warning Systems Consortium (REWSC) Memorandum of Understanding' <https://www.cdema.org/news-centre/press -releases/2015-cdema-and-cardi-sign-regional-early-warning-systems-consortium-rewsc -memorandum-of-understanding>.

48 CDEma, 'CDEMA Launches New Caribbean Risk Information System Platform' < https:// www.cdema.org/news-centre/press-releases/2097-cdema-launches-new-caribbean-risk -information-system-platform>.

49 See UNDRR, 'Annual' (n 15) 37.

$50 \quad$ UNDRR, 'Haiti Approves a New Risk and Disaster Management Plan' (25 July 2020) $<$ https://www.undrr.org/news/haiti-approves-new-risk-and-disaster-management-plan>.

$5^{1}$ Government of the Commonwealth of Dominica, 'Dominica Climate Resilience and Recovery Plan 2O2O-203o' <http://www.dominica.gov.dm/images/documents/CRRP-Final -042020.pdf>. 
legal framework and engaged in extensive peer knowledge exchanges ahead of its drafting of a new disaster risk management law. ${ }^{52}$

\section{$6 \quad$ Where Now after 2020?}

The onslaught of the CoviD-19 pandemic further revealed disaster law pressure points from the local through global levels. While the pandemic itself has served as a hyper-stress test for disaster law frameworks, it is the simultaneity with other acute crises that also must be addressed. As Mami Mizutori, Special Representative of the Secretary-General for Disaster Risk Reduction explains: '... the dynamics of disasters are changing, as demonstrated by the unprecedented COVID-19 pandemic, which highlights the need for a paradigm shift toward a more comprehensive and systemic approach to address multiple hazards simultaneously, to strengthen overall resilience to disasters and place much greater emphasis on tackling risk drivers before the risks themselves materialize. ${ }^{53}$

$52 \quad$ IFRC 'Disaster Law' (n 34) 6.

53 See ECLAC-UNDRR (n 14) 3. 